Industrial Sexuality 
THIS PAGE INTENTIONALLY LEFT BLANK 


\section{Industrial Sexuality}

Gender, Urbanization, and

Social Transformation in Egypt

BY HANAN HAMMAD

University of Texas Press $\underset{v}{ }$ Austin 
Copyright (C) 2016 by the University of Texas Press

All rights reserved

Printed in the United States of America

First edition, 2016

Chapter 1 includes material that previously appeared in H. Hammad, "Making and Breaking the Working Class: Worker Recruitment in the National Textile Industry in Interwar Egypt," International Review of Social History 57 (Dec. 2012):73-96. Copyright (C) Internationaal Instituut voor Sociale Geschiedenis; used by permission of Cambridge University Press. Chapters 5 and 6 include material that previously appeared in H. Hammad, "Between Egyptian 'National Purity' and 'Local Flexibility': Prostitution in al-Mahalla al-Kubra in the First Half of the 20th Century," Journal of Social History 44, no. 3 (Spring 2011): 751-783.

Requests for permission to reproduce material from this work should be sent to:

Permissions

University of Texas Press

P.O. Box 7819

Austin, TX 78713-7819

http://utpress.utexas.edu/index.php/rp-form

(2) The paper used in this book meets the minimum requirements of ANSI/NISO Z39.48-1992 (R1997) (Permanence of Paper).

\section{Library of Congress Cataloging-in-Publication Data}

Names: Hammad, Hanan, author.

Title: Industrial sexuality : gender, urbanization, and social transformation in Egypt / Hanan Hammad.

Description: First edition. | Austin : University of Texas Press, 2016. | Includes bibliographical references and index.

Identifiers: LCCN 2016007756 | ISBN 978-1-4773-1065-6 (cloth : alk. paper) | ISBN 978-1-4773-1072-4 (pbk. : alk. paper) | ISBN 978-1-4773-1111-0 (library e-book) | ISBN 978-1-4773-1112-7 (nonlibrary e-book)

Subjects: LCSH: Egypt-Social conditions-20th century. | Egypt-Economic conditions - 20th century. | Industrialization-Social aspects-Egypt. |

Urbanization-Social aspects-Egypt. | Sex role-Egypt-20th century. | Gender identity-Egypt -20th century. | Working class-Egypt-Social conditions. |

Working class-Egypt-Economic conditions.

Classification: LCC HN786.A8 H34 2016 | DDC 305.30962-dc23

LC record available at http://lccn.loc.gov/2016007756

doi: $10.7560 / 310656$ 
To the memory of my beloved sister Amal-

The love you gave and taught is always with me 
THIS PAGE INTENTIONALLY LEFT BLANK 